\title{
A large Turkish kindred with syndactyly type II (synpolydactyly). 2 Homozygous phenotype?
}

\author{
A Nurten Akarsu, Okan Akhan, Bekir Sitki Sayli, Ugur Sayli, Gülay Baskaya, \\ Mansoor Sarfarazi
}

\begin{abstract}
Syndactyly type II (synpolydactyly (SPD)) is an autosomal dominant condition with typical abnormalities of the distal parts of both upper and lower limbs. We report here a previously undescribed phenotypic feature of people with severe hand and foot deformities who were born to two affected parents. This is the first example of SPD subjects manifesting a very distinctive phenotype, suggesting that they must be homozygous for this condition. The typical characteristic clinical features in these subjects are as follows: (1) short hands with wrinkled fatty skin and short feet; (2) complete soft tissue syndactyly involving all four limbs; (3) polydactyly of the preaxial, mesoaxial, and postaxial digits of the hands; (4) loss of the normal tubular shape of the carpal, metacarpal, and phalangeal bones, so as to give polygonal structures; (5) loss of the typical structure of the cuboid and all three cuneiform bones while the talus calcaneus and navicular bones remain intact; (6) large bony islands instead of metatarsals, most probably because of cuboid-metatarsal and cuneiform-metatarsal fusions; and (7) severe middle phalangeal hypoplasialaplasia as well as fusion of some phalangeal structures that are associated with the loss of normal phalangeal pattern. We report seven subjects with this phenotype from three different branches of a very large SPD pedigree exhibiting the same phenotype with minimal variation. In mice, the Polysyndactyly (Ps) mutation shows a pattern of synpolydactyly very similar to that of human SPD, suggesting that they may well be homologous mutations. A molecular genetic study is currently under way to determine the chromosomal location of the SPD locus in humans and to identify the corresponding homologous region in mice.
\end{abstract}

( $\mathcal{F}$ Med Genet 1995;32:435-441)

Syndactyly type II (synpolydactyly, (SPD)) is a digital malformation affecting mainly the third and fourth fingers of the hands and fifth toes of the feet. This condition is inherited as an autosomal dominant trait with variable expressivity and incomplete penetrance. Homozygosity for SPD appears to be unknown, even in the largest kindred reported so far. ${ }^{12}$ In the preceding paper we described a very large SPD pedigree from the village of Derbent in Turkey. ${ }^{3}$ In this kindred, there are eight sets of marriages in which both parents are affected with SPD. They produced a total of 30 offspring, of whom 27 were affected with SPD. Seven of them show more severe deformity with less phenotypic variation than any other affected people seen in the same kindred, suggesting that they may indeed by homozygous for this condition. In this paper, we present the characteristics of these seemingly homozygous subjects.

Materials and methods

The family structure and results of physical examinations are reported in the preceding paper and summarised on each individual pedigree. ${ }^{3}$ The people with more severe deformities were shown as solid symbols and abbreviated as "CS" below each subject in each pedigree. ${ }^{3}$ The personal identification numbers (PID) of these people in the same pedigrees are given in table 1 for comparison. There is a total of seven subjects showing complete complex syndactyly, all of whom were examined in the field by at least one of us, and $x$ ray films were obtained from five willing subjects.

\section{Results}

CLINICAL FINDINGS

Case 1 (SPD-1, PID 43)

This 30 year old female has short hands and feet with complete soft tissue syndactyly involving all four extremities (fig 1A,B). She was born to two affected parents with typical phenotypic expression of SPD (SPD-1, PID 17 and PID 18). ${ }^{3}$

The upper limbs are "paw-like" and have "cat's paw" appearance. Both hands display complete soft tissue syndactyly involving all fingers, and the thumb and forefinger are extremely rudimentary. The remaining digits are within the mass of this soft tissue. The nails of the first two fingers are hypoplastic, but the others are hardly detectable within this mass. The left hand differed somewhat in that the third finger is identifiable and there is an enlarged nail, probably representing the fourth or more fingers. The "paw-like" appearance was further aggravated by a large amount of wrinkled and fatty skin over the dorsum and by camptodactyly of the digits (fig 1A). Palpation of the hands also gave the impression that some bones were missing under the skin.

$X$ rays of the hands showed patches of abnormal bone, beginning at the carpal level all the way to the third phalanx (fig 1C). In par- 
Table 1 The corresponding personal identification numbers (PID) of homozygotes in the previously reported circular and individual pedigree. ${ }^{3}$

\begin{tabular}{llcl}
\hline Subjects & Family No in each pedigree & \multicolumn{2}{l}{ PID numbers in pedigree } \\
\cline { 3 - 4 } & & Individual & Circular \\
\hline Case 1, female & SPD-1 & 43 & $\mathrm{VI} \cdot 4$ \\
Case 2, female & SPD-1 & 74 & $\mathrm{VII} \cdot 4$ \\
Case 3, male & SPD-1 & 75 & $\mathrm{VII} \cdot 5$ \\
Case 4, female & SPD-1 & 45 & $\mathrm{VI} \cdot 5$ \\
Case 5, female & SPD-2 & 44 & $\mathrm{VI} \cdot 34$ \\
Case 6, female & SPD-2 & 45 & VI·35 \\
Case 7, female & SPD-3 & 109 & VII $\cdot 14$ \\
\hline
\end{tabular}

ticular, the normal tubular shape of the metacarpals and phalanges was lost and was substituted by some cuboidal or polygonal bony structures. Similarly, although to a lesser extent, the carpal bones were transformed into cuboidal forms with partial fusion. Carpometacarpal lines were hardly identifiable. Up to six consecutive abnormal bones in two rows replaced the metacarpal bones (fig 1C). These structures may be tandem duplication of rudimentary and abnormal metacarpals.

There were eight bony structures on the right hand and seven on the left hand which replaced normal digits, so that both pre- and postaxial

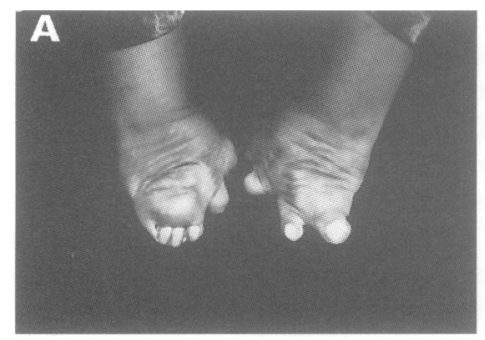

polydactyly were present. The bones in the thumb formation were extremely hypoplastic and deformed with an articulation defect. The second digits were similarly abnormal, in that either the middle phalanx was absent or the presence of the distal bone was the result of fusion of the middle and distal phalanges. Middle phalangeal hypoplasia/aplasia was noted in all fingers as well as brachymetaphalangism. In the postaxial region, there was one abnormal bone on the left and two on the right, possibly representing little fingers. In addition to these abnormalities, the middle and distal phalanges of the fourth and fifth fingers were synostotic on the left side. The feet were similarly short and exhibited complete soft tissue syndactyly. The big toe was normal on both sides, but their nails were extremely hypoplastic (fig 1B). The distance between the big toe and the subsequent complex of toes was enlarged. The second toe was hypoplastic and was attached to a complex in which other toes were not discernible individually.

$X$ ray examination of the feet showed normal talus, calcaneus, and navicular bones, whereas all three cuneiform bones were indistinguish-
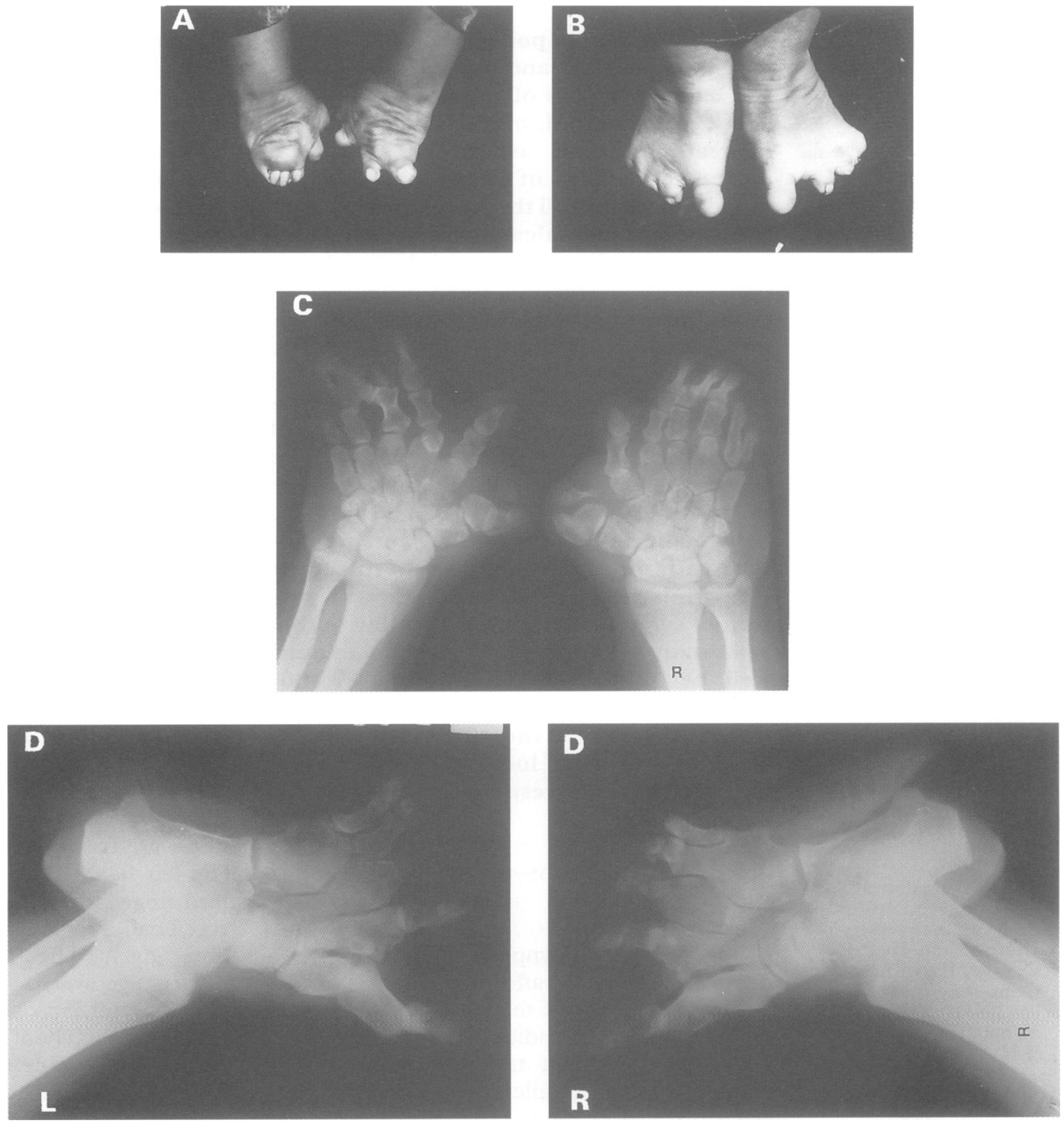

Figure 1A-D Hands and feet of case 1 (subject 43, SPD-1) with characteristic manifestation of the SPD homozygous phenotype. 
Table 2 Clinical manifestations

\begin{tabular}{|c|c|c|c|c|c|c|c|}
\hline $\begin{array}{l}\text { Physical } \\
\text { examination }\end{array}$ & $\begin{array}{l}\text { Case 1 } \\
\text { (Fam1, PID 43) }\end{array}$ & $\begin{array}{l}\text { Case } 2 \\
\text { (Fam1, PID 74) }\end{array}$ & $\begin{array}{l}\text { Case } 3 \\
\text { (Fam1, PID 75) }\end{array}$ & $\begin{array}{l}\text { Case } 4 \\
\text { (Fam1, PID 45) }\end{array}$ & $\begin{array}{l}\text { Case } 5 \\
\text { (Fam2, PID 44) }\end{array}$ & $\begin{array}{l}\text { Case } 6 \\
\text { (Fam2, PID 45) }\end{array}$ & $\begin{array}{l}\text { Case } 7 \\
\text { (Fam3, PID 109) }\end{array}$ \\
\hline $\begin{array}{l}\text { Age } \\
\text { Sex }\end{array}$ & $30 y$ & $8 \mathrm{y}$ & $5 y$ & $19 \mathrm{y}$ & $8 \mathrm{y}$ & $4 \mathrm{y}$ & $4 \mathrm{y}$ \\
\hline $\begin{array}{l}\text { Sex } \\
\text { Associated findings }\end{array}$ & $\begin{array}{l}\mathbf{F} \\
-\end{array}$ & $\begin{array}{l}F \\
-\end{array}$ & $M$ & $\mathbf{F}$ & $\begin{array}{l}F \\
-\end{array}$ & $\mathbf{F}$ & $\mathrm{F}$ \\
\hline \multicolumn{8}{|l|}{ Hands } \\
\hline Short hands & + & + & + & + & + & + & + \\
\hline "Paw-like" appearance & + & + & + & + & + & + & + \\
\hline $\begin{array}{l}\text { Wrinkled and fatty } \\
\text { skin }\end{array}$ & + & + & $+1-$ & + & + & + & + \\
\hline Camptodactyly & + & + & + & + & + & + & + \\
\hline Hypoplastic nails & 1st \& 2nd fingers & - & $\begin{array}{l}\text { 1st \& 2nd fingers } \\
\text { on left }\end{array}$ & - & - & - & - \\
\hline Complete syndactyly & $\begin{array}{l}\text { Partial in 1st \& } \\
\text { 2nd digits }\end{array}$ & $\begin{array}{l}\text { Partial in 1st \& } \\
\text { 2nd digits on } \\
\text { right }\end{array}$ & $\begin{array}{l}\text { Except 1st on } \\
\text { right, 2nd on left }\end{array}$ & $\begin{array}{l}\text { Partial 1st \& 2nd } \\
\text { digits }\end{array}$ & $\begin{array}{l}\text { Partial 1st \& 2nd } \\
\text { digits on left }\end{array}$ & All fingers & $\begin{array}{l}\text { With duplicated } \\
\text { thumb and partial } \\
\text { syndactyly 1st \& } \\
\text { 2nd digits }\end{array}$ \\
\hline \multicolumn{8}{|l|}{ Feet } \\
\hline Short feet & + & + & + & + & + & + & + \\
\hline $\begin{array}{l}\text { Complete syndactyly } \\
\text { from } 2 \text { nd } \& 5 \text { th toes }\end{array}$ & + & + & + & + & All toes & + & + \\
\hline $\begin{array}{l}\text { Hypoplastic nails } \\
\text { of big toe }\end{array}$ & + & $+1-$ & + & - & - & + & + \\
\hline $\begin{array}{l}\text { Increased distance } \\
\text { between hallux and } \\
\text { subsequent complex }\end{array}$ & + & + & + & + & - & - & + \\
\hline
\end{tabular}

Table $3 X$ ray examination findings

\begin{tabular}{|c|c|c|c|c|c|c|c|}
\hline $\begin{array}{l}X \text { ray } \\
\text { findings }\end{array}$ & $\begin{array}{l}\text { Case } 1 \\
\text { (Fam1, PID 43) }\end{array}$ & $\begin{array}{l}\text { Case } 2 \\
\text { (Fam1, PID 74) }\end{array}$ & $\begin{array}{l}\text { Case } 3 \\
\text { (Fam1, PID 75) }\end{array}$ & $\begin{array}{l}\text { Case } 4 \\
\text { (Fam 1, PID 45) }\end{array}$ & $\begin{array}{l}\text { Case } 5 \\
\text { (Fam2, PID 44) }\end{array}$ & $\begin{array}{l}\text { Case } 6 \\
\text { (Fam2, PID 45) }\end{array}$ & $\begin{array}{l}\text { Case } 7 \\
\text { (Fam3, PID 109) }\end{array}$ \\
\hline \multicolumn{8}{|l|}{ Hands } \\
\hline Normal radius/ulna & + & + & + & Not examined & + & + & \multirow{8}{*}{ Not examined } \\
\hline $\begin{array}{l}\text { Loss of normal tubular } \\
\text { shape of carpal, }\end{array}$ & + & + & + & & + & + & \\
\hline $\begin{array}{l}\text { metacarpal, and } \\
\text { phalangeal bones }\end{array}$ & & & & & & & \\
\hline $\begin{array}{l}\text { Severe } \\
\text { brachymetaphalangism }\end{array}$ & + & + & + & & + & + & \\
\hline Preaxial polydactyly & + & + & - & & + & + & \\
\hline $\begin{array}{l}\text { Postaxial/mesoaxial } \\
\text { polydactyly }\end{array}$ & + & + & + & & + & $?$ & \\
\hline $\begin{array}{l}\text { Middle phalanx } \\
\text { hypoplasia/aplasia }\end{array}$ & + & + & $?$ & & + & $?$ & \\
\hline $\begin{array}{l}\text { hypoplasia/aplasia } \\
\text { Triphalangeal thumb }\end{array}$ & - & + & - & & - & - & \\
\hline \multirow{2}{*}{\multicolumn{8}{|c|}{ Feet }} \\
\hline & & & & & & & \multirow[t]{8}{*}{ Not examined } \\
\hline $\begin{array}{l}\text { Normal talus, } \\
\text { calcaneus, and } \\
\text { navicular bones }\end{array}$ & + & + & + & & + & Navicular? & \\
\hline $\begin{array}{l}\text { Large bony islands } \\
\text { replacing cuboid and }\end{array}$ & + & + & + & & + & + & \\
\hline $\begin{array}{l}\text { 5th metatarsals } \\
\text { Fused metatarsals } \\
\text { with respective } \\
\text { three cuneiforms }\end{array}$ & + & + & + & & + & + & \\
\hline $\begin{array}{l}\text { Tibial deviations of the } \\
\text { big toe }\end{array}$ & + & + & + & & - & + & \\
\hline Triphalangeal hallux & - & + & - & & $?$ & ? & \\
\hline $\begin{array}{l}\text { Middle phalanx } \\
\text { hypoplasia }\end{array}$ & + & + & + & & $?$ & ? & \\
\hline $\begin{array}{l}\text { Loss of normal } \\
\text { phalangeal structure } \\
\text { from } 2 \text { nd to } 5 \text { th toes }\end{array}$ & + & + & + & & + & + & \\
\hline
\end{tabular}

able from the fused metatarsal bones (fig 1D). The cuboid bone was completely lost and was substituted by a large polygonal bony structure, probably representing the cuboid as well as the fourth and fifth metatarsal bones. These bony islands did not allow the tarsal and metatarsal bones to be distinguished. No extra digit was present on either side. The distal phalanx of the big toe was rudimentary. All of the phalangeal structures lost their normal tubular appearance, and the middle phalanges were extremely hypoplastic or even absent on both sides. On the right, the proximal phalanges of the third and fourth toes were fused with abnormal metacarpal structures. There were similar findings on the left, except for the presence of a metatarsophalangeal fusion.

There was no associated abnormality in this person. Pedigree data in our previous work indicated that the subject belonged to a sibship of 10 , of whom nine are affected. ${ }^{3}$ All of the affected sibs showed typical features of SPD, except one (PID 45) (tables 2 and 3). Both of the parents were affected with typical SPD. However, the mother showed an enlarged hallux on the right foot, which may suggest preaxial polydactyly. The husband (PID 44) also has typical features of synpolydactyly and two offspring are affected with similar complex complete syndactyly.

Case 2 (SPD-1, PID 74)

This 8 year old female has bilaterally short hands with a typical "paw-like" appearance (fig 2A). On her right hand, the first and second digits are distinguishable and there is complete soft tissue syndactyly involving the remaining digits. On her left hand, none of the digits except the thumb were discernible separately within the mass. Her nails are normal and there is camptodactyly involving all digits bilaterally. 

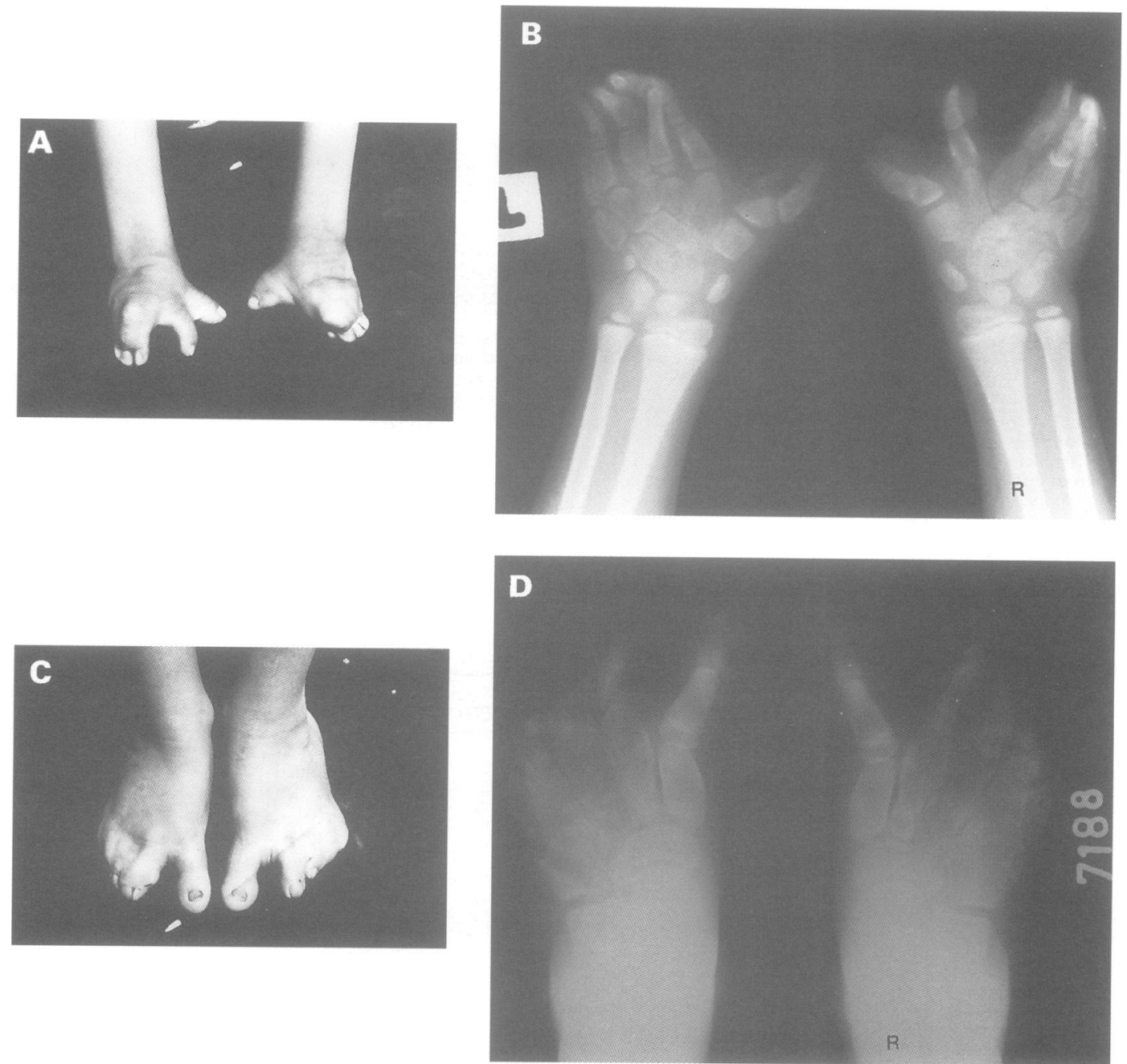

Figure $2 A-D$ Hands and feet of the second homozygous case (subject 74, SPD-1) showing triphalangeal first digit in both hands and feet.

Palpation gave the impression that some bones may be missing under the skin, being masked by wrinkled and fatty skin over the dorsum.

There was an increased distance between the mass and the index finger.

$X$ ray examination showed normal radial and
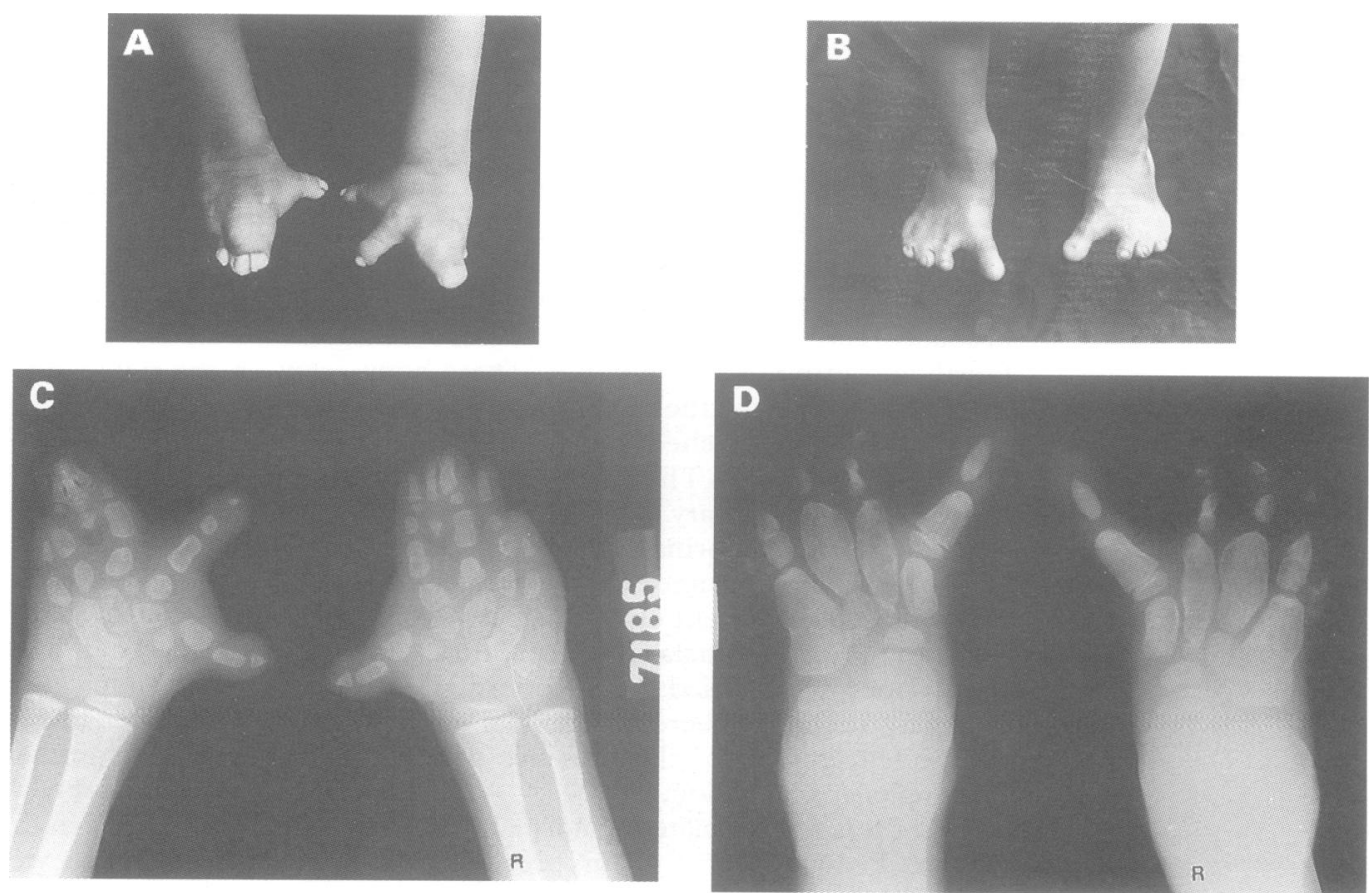

Figure $3 A-D$ Hands and feet of case 3 (subject 75, SPD-1). 

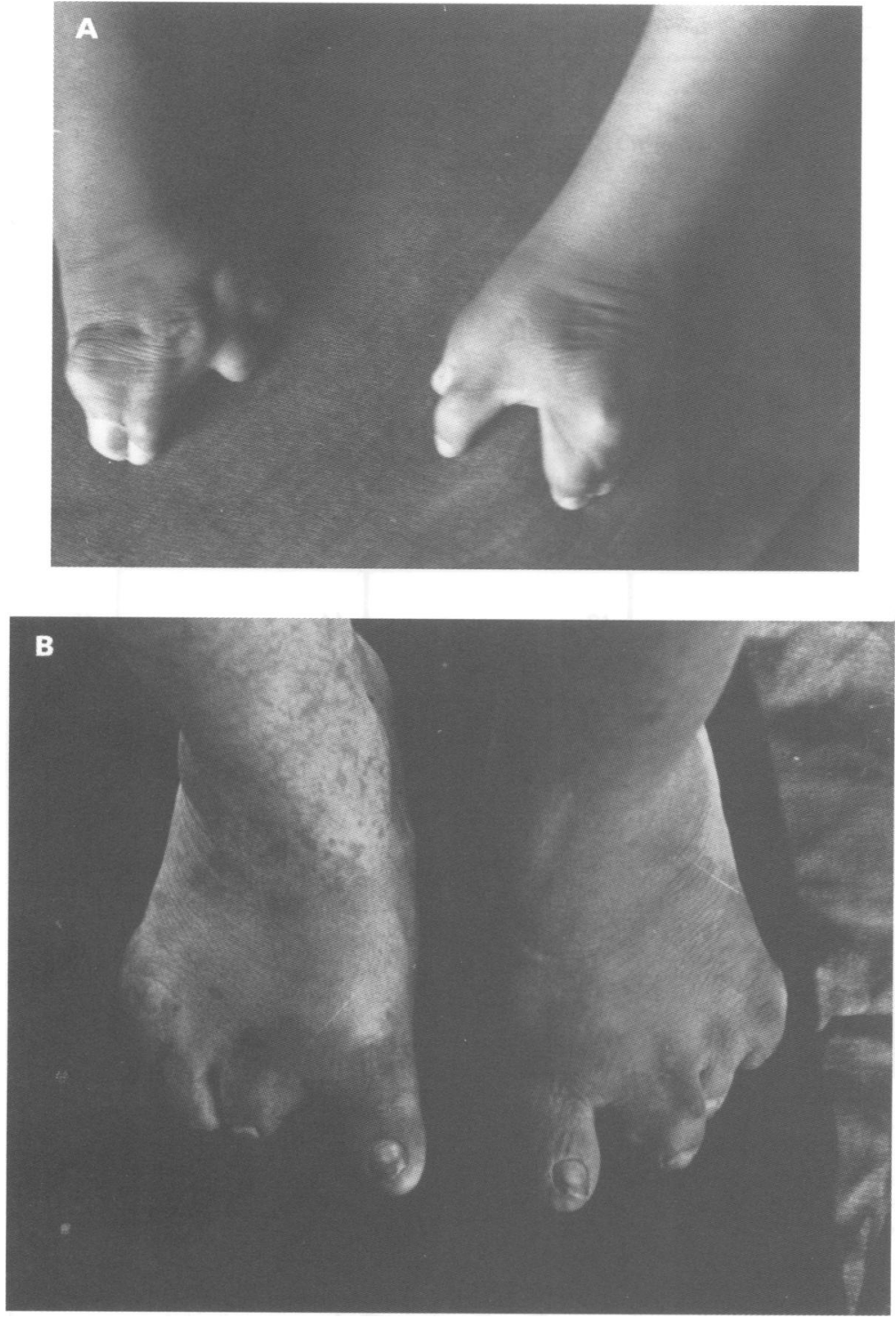

Figure $4 A, B$ Hands and feet of case 4 (subject 45, SPD-1).
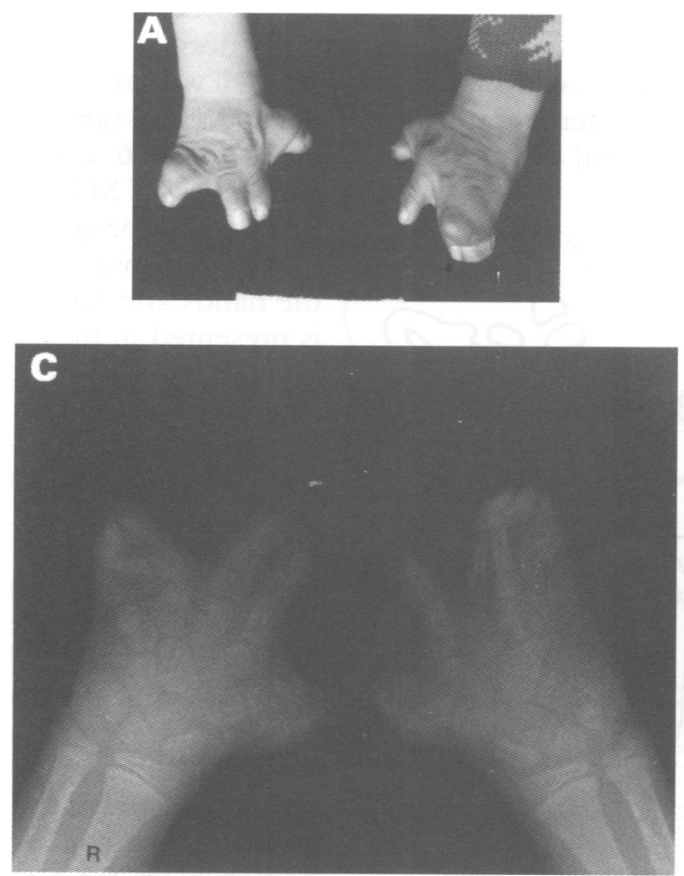

ulnar bones on both sides. Abnormal development has apparently started from the carpal boundary (fig 2B). Briefly, the carpal bones have lost their normal shape and are substituted by bony islands. All of the carpometacarpal bones are replaced by polygonal or cuboid structures. Bony fusion was noted at the carpal level bilaterally. Six bony structures and triphalangeal thumbs constitute the fingers of both hands. Additionally, a small piece of extra bone is present next to both thumbs. There was bony fusion between the proximal, middle, and distal phalanges on the third and fourth digits of the right hand only.

In the foot, the halluces were found to be normal, whereas the other toes were within the mass of soft tissue (fig $2 \mathrm{C}$ ). $X$ ray examination showed normal talus, calcaneus, and navicular bones. There were large bony islands resulting from fusion of the cuneiform-metatarsal and cuboid-metatarsal bones (fig 2D). No extra toe was present, but all toes have lost their normal shape and the phalanges were hardly discernible. A triphalangeal hallux with its tibial deviation is the additional feature of this phenotype.

\section{Other cases}

The phenotypes of cases 3 (fig 3A-D), 4 (fig 4A,B), 5 (fig 5A-D), 6, and 7 are strikingly similar to those of the above mentioned cases and are summarised in tables 2 and 3.

\section{PEDIGREE ANALYSIS}

We have identified eight marriages between two affected people. One of these is a marriage between a homozygote and a heterozygote (SPD-1 PIDs 43 and 44$)^{3}$ producing two homozygous offspring. In the other marriages both parents are heterozygotes. Eight marriages
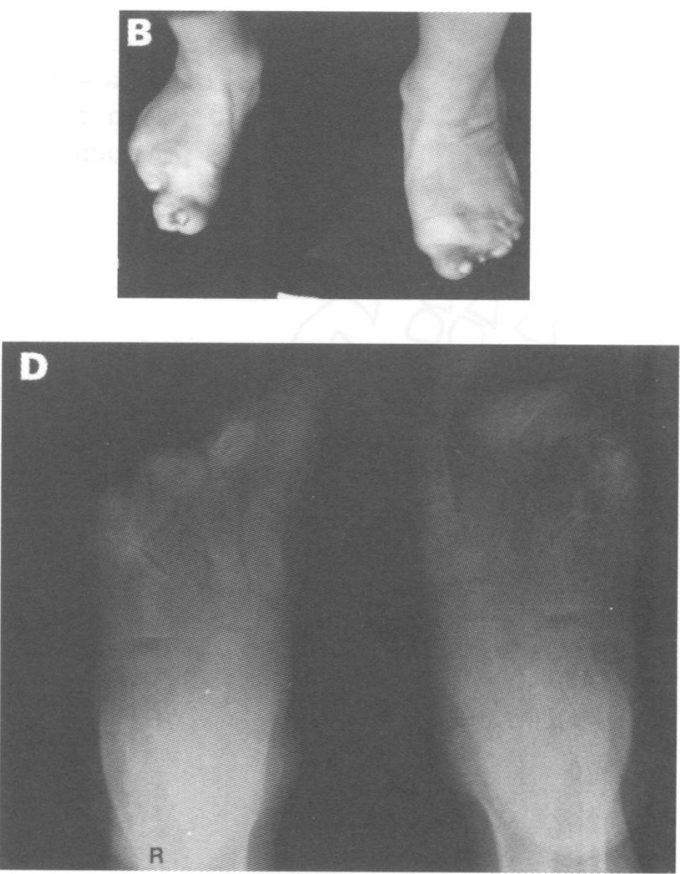

Figure 5A-D Hands and feet of case 5 (subject 44, SPD-2). 


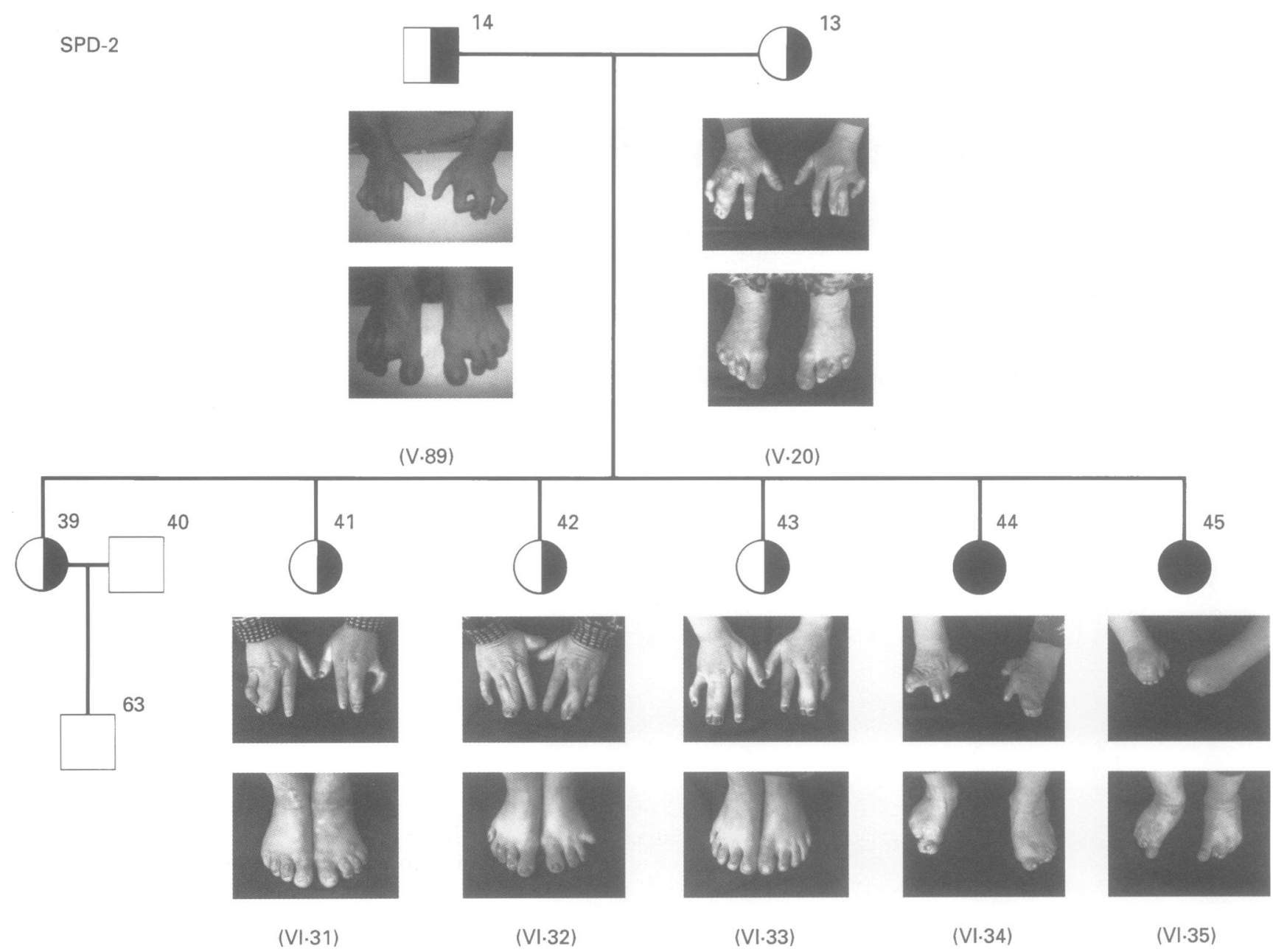

Figure 6 Inheritance of the homozygous and heterozygous subjects in one branch of the SPD-2 pedigree. ${ }^{3}$ The segregation and phenotypic expression in the hands and feet in the homozygous subjects (persons 44 and 45) are shown for comparison with their heterozygous parents and sibs. The location of each subject in the circular pedigree ${ }^{3}$ is indicated below each subject.

produced a total of 30 offspring, 27 affected and three unaffected. Seven of the 27 affected subjects exhibited more severe features, suggesting homozygosity at the genetic level. Furthermore, despite the fact that they come from different branches of the same kindred, there are close phenotypic similarities among them. Seven of the above mentioned eight marriages were between two typical heterozygote SPD parents producing a grand total of 25 affected
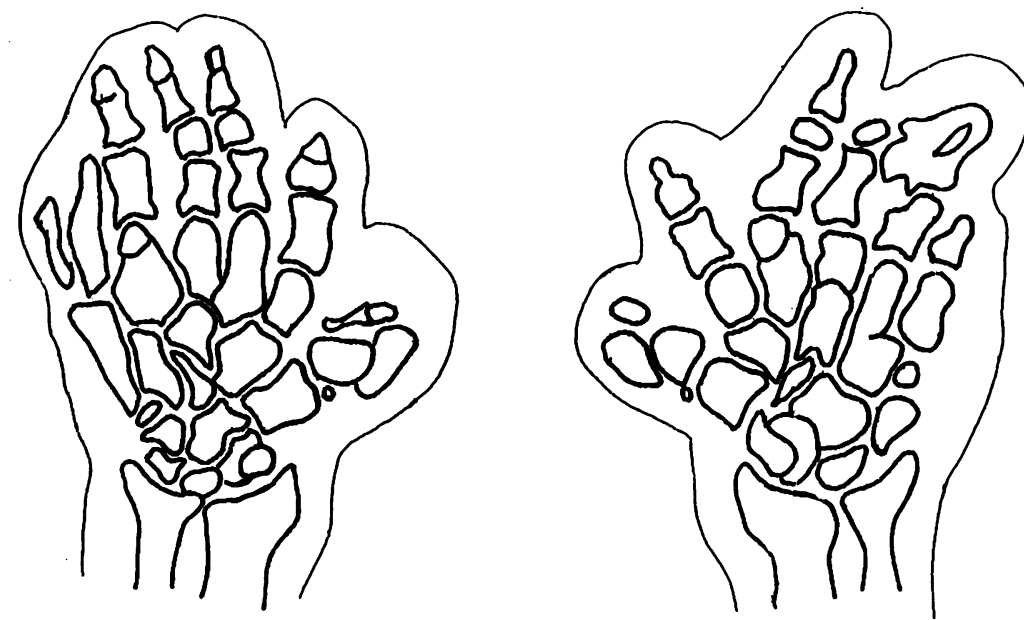

Figure 7 Drawings of the homozygote's hands representing changes in the normal tubular formation of the bones. See text for details. (expected $\mathrm{n}=21$ ) and three normal (expected $\mathrm{n}=7$ ) offspring. Only one marriage was noted between an SPD heterozygote and homozygote producing two affected (expected $n=2$ ) and no normal (expected $n=0$ ) offspring. The observed frequencies of a total of 27 affected and three normal offspring in these eight matings are well within the expected values of 23 affected and seven normal offspring $\left(\chi_{1}^{2}=2 \cdot 98, \mathrm{p}=\right.$ 0.084). Fig 6 exemplifies the "homozygous phenotype of SPD" as compared with typical SPD of heterozygous parents and sibs. A drawing of the observed characteristic features in the hands and feet of these homozygous cases is presented in fig 7 and 8 respectively.

\section{Discussion}

To the best of our knowledge, this work presents the first cases of people with severe hand and foot deformities who were born to two parents affected with SPD. The phenotypic expression is uniquely different from other patients affected with SPD (that is, heterozygotes) who are usually born to one affected and one normal parent. So, at the genotypic level, the subjects presented here must be homozygous for the SPD gene, representing yet another phenotypically detectable example of homozygotes for a rare autosomal disorder. ${ }^{45}$ The characteristic findings in these subjects 


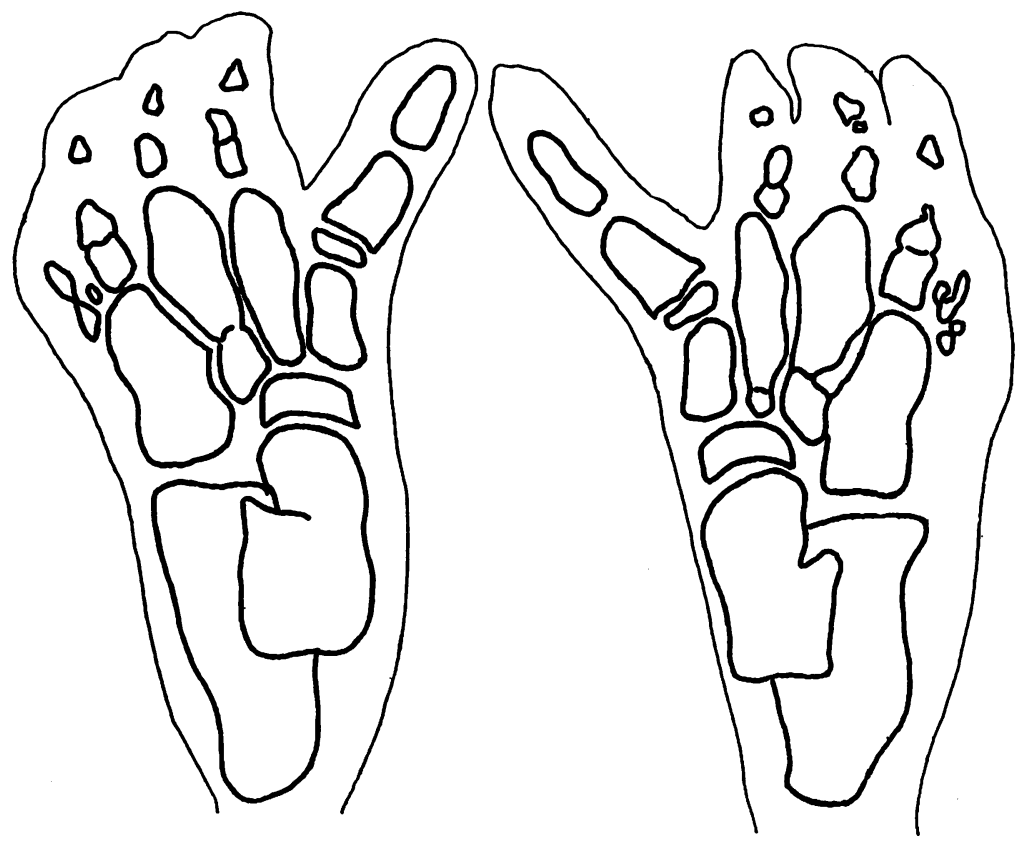

Figure 8 Drawings of the homozygote's feet showing changes in the normal tubular formation of the bones. See text for details.

are: (1) short hands with wrinkled fatty skin and short feet; (2) complete soft tissue syndactyly involving all four limbs; (3) polydactyly on preaxial, mesoaxial, and postaxial areas of the hands; (4) loss of normal tubular shape of carpal, metacarpal, and phalangeal bones leading to polygonal structures; (5) loss of typical structures of the cuboid and all three cuneiform bones, with the talus, calcaneus, and navicular bones remaining intact; (6) large bony islands of metatarsals, most probably arising from cuboid-metatarsal and cuneiform-metatarsal fusions; and (7) severe middle phalangeal hypoplasia/aplasia, together with fusion of some phalangeal structures that are associated with the loss of the normal phalangeal pattern. There is little variation between the left and right hands (if any) as shown by $x$ rays indicating a "mirror effect". On $x$ ray examination, this phenotype can be easily distinguished from the other types of complete syndactyly. ${ }^{67}$ Thus, this unusual phenotype must represent homozygosity for the SPD gene.

In mice, syn/polydactyly results from a number of distinct mutations. ${ }^{8}$ In addition to these mutations, Johnson ${ }^{9}$ described another mutant gene which is designated polysyndactyly $(P s)$. The characteristic features of this mutation are the most similar to those described in our patient population, as originally suggested by Winter. ${ }^{10}$ However, homozygous mice die at or before birth. Embryological studies in the mouse showed that cell death of interdigital areas is almost totally absent in fore- and hindfeet in $P s / P s$ mutants, chondrification is poor, and up to six metatarsals can be seen. ${ }^{9}$ Thus, phenotypically, the Ps mutation could be the counterpart of the human SPD mutation in mice. No homology is known between the Ps locus and its counterpart in humans. However, the two flanking loci to the $P s$ locus on mouse chromosome 4 (Pgm-2 and C8b) do show homology with the region $1 \mathrm{p} 36-\mathrm{p} 22$ in hu- mans, ${ }^{8-10}$ providing an excellent candidate region for synpolydactyly. However, a genetic linkage study of DNA markers selected from the entire short arm of chromosome 1 produced a negative lod score in the Derbent kindred. These preliminary linkage studies showed that either the mouse Ps mutation is not the counterpart of SPD in humans or the precise homologous region of the $P s$ locus in the mouse is not the corresponding region of $1 \mathrm{p} 36-\mathrm{p} 22$ in humans.

From an embryological point of view, the differentiation of specific cell types and structures suggest that limb buds have positional information which must relate to the proximodistal, anteroposterior (preaxial-postaxial), and dorsoventral axes. ${ }^{112}$ In this particular phenotype, while the thumb and hallux are situated on the preaxial side of the limb and the fifth digit on the postaxial side, the formation of a correct number of digits and a correct pattern of formation is likely to be defective. The typical SPD phenotype (heterozygous) shows at least a normal pattern formation on positional information. Thus, it is classified as "increased number of digits on the mesoaxial line with normal pattern formation" according to the newly devised classification of Winter and Tickle. ${ }^{12}$ Speculatively, to have such a normal pattern of formation (that is, heterozygous SPD), it seems likely that at least one copy of a normal gene is essential. Positional mapping of the putative gene, mutation identification, and cloning of the eventual molecular defect will solve the synpolydactyly puzzle. Studies are currently under way in our laboratory to identify the chromosomal location of the SPD locus.

We would like to thank the Turkish Ministry of Health, Division of Basic Health Services for providing many facilities including $x$ rays and transport to and from the village of Derbent. We would also like to thank Dr P Erdogdu from the Turkish Ministry of Health for her participation in ascertaining the SPD kindred. We are equally grateful to the proband and her family for travelling from remote areas in order to participate in this study. The authors also express their deepest appreciation to other affected people and their families for participating in the study. This work is supported by an intermural Faculty Research Program from the University of Connecticut Health Center. The work described here was originally presented for fulfilment of a PhD degree (A N Akarsu).

1 Thomsen O. Einige Eigentuemlichkeiten der erblichen Polyund Syndactylie bei Menschen. Acta Med Scand 1927;65:

2 Cross HE, Lerberg DB, McKusick VA. Type II syndactyly. Am f Hum Genet 1968;20:368-80.

3 Sayli BS, Akarsu AN, Sayli U, Akhan O, Ceylaner S, Sarfarazi M. A large Turkish kindred with syndactyly type II (synpolydactyly). 1 Field investigation, clinical and pedigree data. $\mathcal{F}$ Med Genet 1995;32:421-34.

4 Hulten MA, Honeyman MM, Mayne AJ, Tarlow MS Homozygosity in piebald trait. $\mathcal{F}$ Med Genet 1987;24 568-71.

5 Pauli RM. Dominance and homozygosity in man. Am 7 Med Genet 1983;16:455-8.

6 McKusick VA. Mendelian inheritance in man. 10th ed. Baltimore: The Johns Hopkins University Press, 1992.

7 Temtamy SA, McKusick VA. The genetics of hand malformations. In: Birth defects: original article series. Volume XIV (3). New York: Alan R Liss, 1978.

8 Lyon MF, Searle AG. Genetic variants and strains of the laboratory mouse. 2nd ed. Oxford: Oxford University Press, 1989.

9 Johnson DR. Polysyndactyly, a new mutant gene in the mouse. $\mathcal{E}$ Embryol Exp Morphol 1969;21:285-94.

10 Winter RM. Malformation syndromes: a review of mouse/ human homology. $₹$ Med Genet 1988;25:480-7.

11 Moore KL. The developing human. 4th ed. Philadelphia: Saunders International Edition, 1988.

12 Winter RM. Tickle C. Syndactylies and polydactylies: embryological overview and suggested classifications. Eur $\mathcal{F}$ Hum Genet 1993;1:96-104. 